\title{
WAYS OF PROTECTION FROM NOISE POLLUTION IN RAILWAY AND TRAMWAY INFRASTRUCTURE
}

\author{
Paulina Szabłowska ${ }^{1}$, Maciej Rochel ${ }^{2 *}$ \\ ${ }^{1}$ Cracow University of Technology, Faculty of Civil Engineering, Chair of Highway and Traffic Engineering, Poland, e-mail: paulinaszablowskaa@gmail \\ ${ }^{2}$ Cracow University of Technology, Faculty of Civil Engineering, Chair of Highway and Traffic Engineering, Poland, e-mail: maciek.rochel@gmail \\ ${ }^{*}$ Corresponding author
}

Reviewed positively: 28.01 .2020

Information about quoting an article:

Szabłowska P., Rochel M. (2020). Ways of protection from noise pollution in railway and tramway infrastructure. Journal of civil engineering and transport. 2(1), 35-45, ISSN 2658-1698, e-ISSN 2658-2120, DOI: 10.24136/tren.2020.003

\begin{abstract}
The paper presents various ways of protection from traffic noise used in railway infrastructure in Poland. The sources of noise in rail and tram transport were discussed. Also commonly found solutions on the railway network were analyzed such as noise barriers and rail dampers. Modern tram surfaces have been presented as one of the noise protection methods in the tram infrastructure. In the tram infrastructure a noise protection method was presented in the form of tram track lubricators on sharp curves. In addition, the effectiveness of noise protection methods was assessed on the basis of tests and research.
\end{abstract}

Key words - railway, tramway, infrastructure, noise pollution

JEL Classification - R41

\section{INTRODUCTION}

These days we are virtually overloaded by sounds. Whenever we go to work or spend time with a family sounds and music are present. It could be our favorite music, sounds from commercials or traffic noise that is mainly produced by vehicles. It wouldn't be such a problem when these sounds weren't noisy and hard to bear for the average human being.

Many studies have shown the damaging effect of environmental noise on people's health. Prolonged exposure can cause hearing impairment, sleep disturbance and poor concentration. That is why it can be regarded as one of the most important public health issue.

When it comes to the noise pollution, it can be divided according to its source. We can distinguish: industrial noise, traffic noise, municipal noise, house or work noise. It is said that traffic noise bears the greatest responsibility for noise pollution [2]. The number of people estimated to be at risk of traffic noise in Europe is 100 million.

I. SOURCE OF NOISE IN RAILWAY AND TRAMWAY INFRASTRUCTURE

TRAFFIC NOISE

As it was mentioned in the first paragraph traffic noise is harmful to people's organism. Researchers say that between $20-30 \%$ of the children and young people have troubles with proper hearing [2].

Traffic noise can be brought on by three basic ways of transport: roads, railways or planes. That is why we differentiate: roadway noise, railway /tramway noise and aircraft noise [1]. This paper focuses on railway/tramway noise.

\section{SOURCES OF RAILWAY AND TRAMWAY NOISE}

As far as railways is concerned, one should realise that its causes are various (Fig. 1). They can be divided into:

ROLLING NOISE

Rolling noise is the most important type of railway noise that is mentioned above. It has the greatest impact on the overall rail noise level. This is because it occurs at the largest and the most common speed range which is between $50-300 \mathrm{~km} / \mathrm{h}$.

The rolling noise is generated in a simple way. Both the track and the wagons (above all the lateral surfaces of their wheels) are vibrated during rolling stock passing through [3]. Despite the small contact area between the wheel and the rail (it is no more than $1,5 \mathrm{~cm}^{2}$ ), this noise is the main reason for railway noise [4]. Rolling noise depends mainly on rail corrugation (unevenness occurring) within 
wheel turning zones and railways. The surface roughness during the journey contributes to the vertical vibrations of both vehicles and rails. The material transmits vibrations that create sound ray in each of the elements. Finally this leads to the creation of sound that causes noise [3].

\section{AERODYNAMIC NOISE}

Another source of noise is aerodynamic noise. It can be mainly found in high speed trains. That's because aerodynamic noise increases above the speed $250-300 \mathrm{~km} / \mathrm{h}$. It is caused by an aerodynamic drag that comes from the unequal air flow during the train run.

The difference between this kind of railway noise and others is that it doesn't come from solid vibrations but arises due to the movement of elements in the air. In addition to speed, the main physical factors such as a shape and a height have an impact on an aerodynamic drag [5]

\section{TRACTION NOISE}

Traction noise can be described as a kind of noise that is associated with the operation of an electric or internal combustion engine. It is also connected with sound of current collector movement through contact wire of overhead contact line. There are also other factors that make up the traction noise such as sound of working compressor or cooling process. It can be even connected with exhaust gas.

Vehicle's speed contributes mostly to the traction noise. However there are still some other factors as: type and power of engine and its speed of rotation, type of used freezing system and type of vehicle [3].

\section{OTHERS}

As it was mentioned above there are also some other sources of railway/tramway noise. Among them we can distinguish an acceleration noise. This type of noise occurs due to the friction of the brake blocks on the wheel. This is a key noise factor in areas near railway stations. In the same area there is also braking noise that is connected with working engine sound [6].

In other cases there is also a noise, which comes from train wheels squeak on track arch. It occurs mainly on small radius arch, so this is the dominant

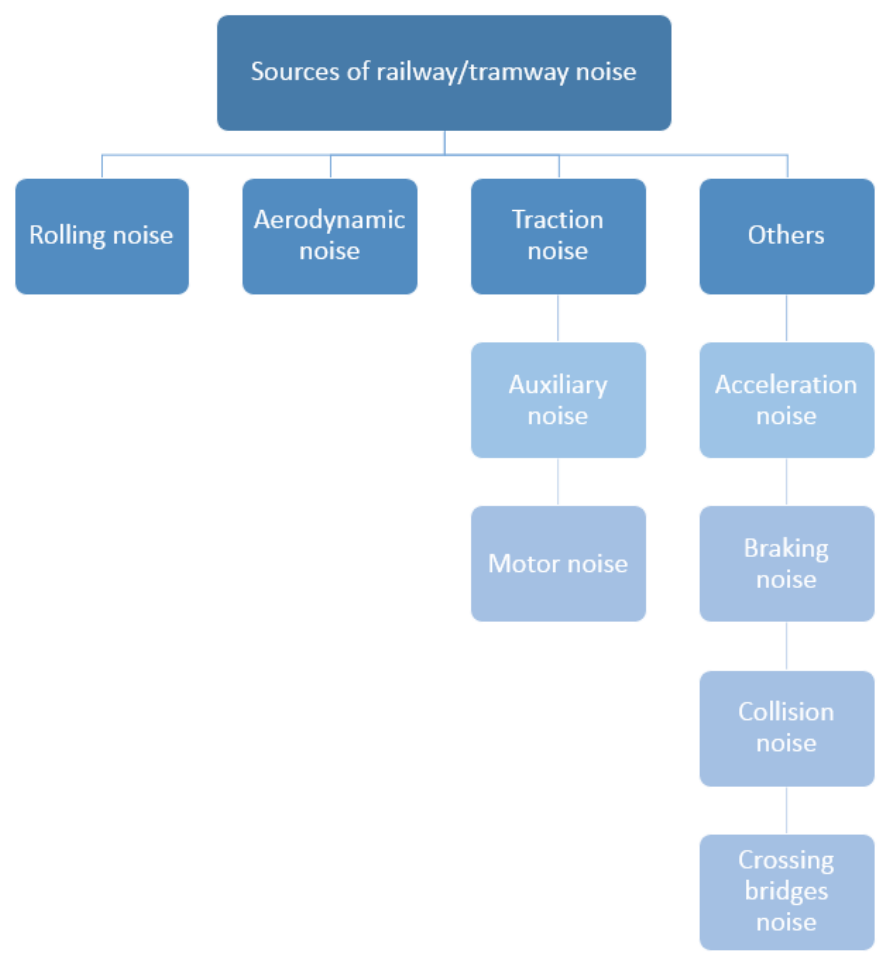

Fig. 1. Sources of railway noise - based on [3] 
factor source of noise in the tram infrastructure. It is also worth paying attention to the noise generated in the area of engineering structures, such as bridges. There are also occasional types of noise, e.g. accidental/collision noise.

\section{WAYS OF PROTECTION FROM NOISE POLLUTION IN RAILWAY}

Nowadays, due to the increasing people's awareness about the harmful effects of noise on health, more and more solutions reducing noise are emerging. Both the effectiveness and the way they are used are different and give various effects.

\section{METHODS OF PROTECTION DUE TO} THE PLACE OF ACTION

When we talk about railway noise pollution protection we need to realize that two solutions can be found and applied (Fig. 2).

They are recognized by the place in which noise pollution is being solved.

The former is connected with methods of reducing noise at the place of origin. It is mainly related to works on the railway surface or rolling stock elements. It usually requires direct works related to railway infrastructure.

The latter consists of solutions that are used at the place of spread. This method involves application/implementation the construction of protective elements outside railway infrastructure. It can be easily used on existing railways.
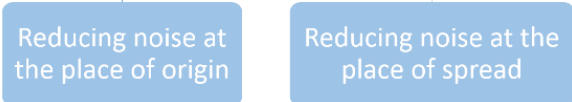

Fig. 2. Types of noise protection - based on [9]

REDUCING NOISE AT THE PLACE OF ORIGIN

This type of protection can be split into three parts (Fig. 3). The first of them is related to activities based on rolling stock. Next is related to the operation and maintenance of the railway infrastructure and last is about introducing new devices into the existing railway infrastructure, in particular railway surface. This devices are installed to reduce friction between rail and wheel.

\section{ROLLING STOCK SOLUTIONS}

The simplest and the most effective method of reducing noise is the replacement of rolling stock with newer generation vehicles. Unfortunately, this is not the cheapest method but it highly efficient because modern vehicles have strictly defined acceptable noise emission parameters. In comparison to vehicles from the 1960s-1980s they should emit a noise lower by a minimum of $10 \mathrm{~dB}$ [7].

Other method of protection is modernization of rolling stock. It is slightly cheaper way yet still effective. It can reduce noise up to $8 \mathrm{~dB}$. This can be achieved mainly due to the replacement of steel brake blocks with composite ones and the installation of wheel springs or sound shields for traction devices [7-9].

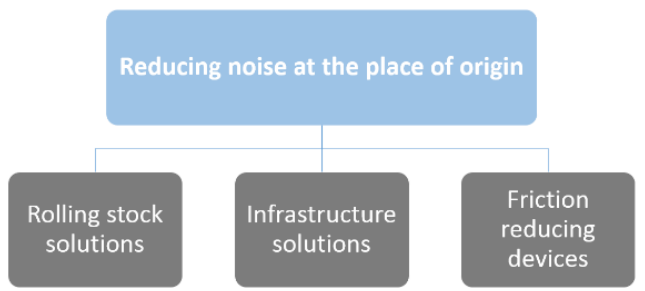

Fig. 3. Types of reducing noise at the place of origin - based on [7]

\section{INFRASTRUCTURE SOLUTIONS}

The second group of noise reduction solutions is directly related to the railway surface. The first involves modernization of old, damaged infrastructure with outdated technology. As in rolling stock case, it is also expensive and it cannot be made too often [7]. At this point, another positive aspect of railway infrastructure modernization based on changing the type of railway traffic-control devices should also be seen The new devices allow the flow of traffic, which reduces the number of brakes and train starts. It also helps to reduce noise.

The idea that gives measurable benefits is to keep the railway infrastructure in good condition. This can be ensured mainly by grinding the running surface of the rails and the use of rail shock absorber systems (to ensure better elasticity). It is also important to replace the old rail crossings with new ones and to abandon the classic track for a Continuously Welded Rail [7].

Both modernization and renovation have a noticeable effect in terms of absorption and suppression of acoustic nuisance, which also has a positive translation to reduce noise emissions [10]. Just grinding the rails is able to compress noise by $3 \mathrm{~dB}$. Modernization or renovation involving at least the replacement of the surface leads to absorption and damping of sound at even $10 \mathrm{~dB}$ (depending on the speed) [9].

FRICTION REDUCING DEVICES

This method consists of special elements that 
are installed mainly in the railway surface or next to it. Specific solutions include lubricants and a vibroacoustic isolators.

Lubricants are most often used in case of arches with small radii. Its effectiveness is similar to rails grinding - it is up to $3 \mathrm{~dB}$ [9]. In this case, noise is reduced by the automatic application of the lubricant which are spread on the rails by the wheels of rolling stock. Not only is noise reduced but also rail and wheel rim surface degradation occurs more slowly.

As far vibroacoustic isolators we need to know that there is a wide selection of different products. They are all connected by one principle - they suppress vibrations. The choice of the type of vibroacoustic isolator depends on railway surface that we use and the type of vibration. For example, while using ballast track, slipper pads are most often used method from vibroacoustic isolators [11]

In addition, we can include rail dampers and track dampers into the category mentioned above. Rail dampers are elements that are located at the neck or foot of the rail. These dampers are mounted at equal distances. Their operation is based on multiplication of expiration vibration along the rail length, and thus reduction of acoustic nuisance. Track dampers are elements that are part of railway surface. They are installed on the top layer of sleepers or on concrete slabs. The assembly of these elements takes place between the courses on the rail as well as on the side of the track guides. The operation of these devices is based on two mechanisms, which are absorption and dispersion of sound waves [12].

\section{REDUCING NOISE AT THE PLACE OF SPREAD}

This type of protection against noise involves placing a barrier between the source of sound production and its receiver. Their undoubted advantage is the possibility of using them outside the railway infrastructure. We can divide them into three groups (Fig. 4):

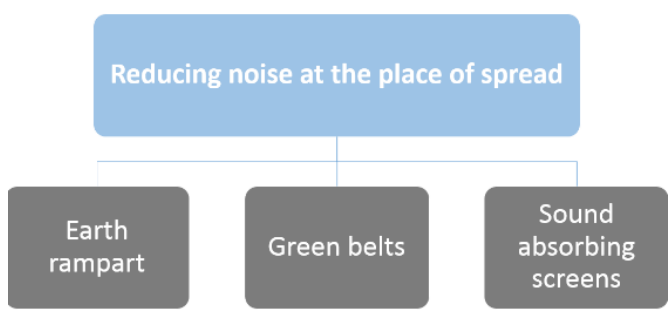

Fig. 4. Types of reducing noise at the place of spread - based on [7]

\section{EARTH RAMPARTS}

This method involves creating excavations and embankments along the railway line. It is ecologica and is characterized by high durability. Its basic disadvantage is the need to occupy a wide strip of land. Nevertheless, this method allows noise reduction by up to $25 \mathrm{~dB}$. The level of noise reduction depends on the width and height of the rampart [7].

GREEN BELTS

The method is based on planting vegetation. It is certainly the most visually attractive method, but its effectiveness is not very high. The solution is able to reduce acoustic nuisance only by $0.01-0.5$ $\mathrm{dB}$ depending on the type of vegetation used (applies to a green belt width of $1 \mathrm{~m}$ ). The most effective are hedges and conifers [7].

\section{SOUND SCREENS}

It is the most commonly used method of noise reducing at the place of spread. There are also three types of protection screens.

First of them is sound insulation screen. This method of action is based on reflecting the sound wave. Next one is sound absorption screen. They have a dual effect. On the one hand they also reduce noise by reflecting but on the other they absorb some energy in the form of sound. The last form is diffusing screen. They work on the principle of disintegration of the acoustic wave [7].

The biggest advantage about that kind of method is low land occupancy. This method allows noise reduction by up to $8-15 \mathrm{~dB}$ (depended on many factors, such as: barrier height, topography, etc.). Effectiveness largely depends on the correct design and implementation [7].

Screen performance is determined by meeting specific conditions, including relevant geometric parameters. A well-designed screen must be of suitable height and length and must not have breaks in the structure. The lack of screen continuity causes a drastic reduction in the effectiveness of its operation. The first step in designing an acoustic screen should be to recognize the environmental conditions. A common error is the incorrect use of sound insulation screens, which leads to the phenomenon of wave interference and, as a result, to an increase in noise [22].

\section{SOLUTIONS IN TRAMWAY INFRASTRUCTURE}

As it was mentioned in previous chapter, some of the noise reduction methods in rail transport are noise barriers or rail dampers. These are rare methods of noise protection used in urban rail transport. The tram infrastructure more often uses: 
1. wheel flange lubrication,

2. lubrication of rail heads or flangeways,

3. tram track structure builds in ballastless technology.

Other noise protection measures in the tram infrastructure result from different technical parameters of this infrastructure from the railway. On the tram network occurs sharp curves with the smallest radius of 20-30 meters, where on the rail it is 10 times higher. In addition, tram vehicles are lighter and have shorter wagons. The speed of the vehicles is also important - trams run at a maximum speed of 50 or $70 \mathrm{~km} / \mathrm{h}$. As a result, the aerodynamic noise aspect of a passing vehicle is negligible.

\section{WHEEL FLANGE LUBRICATION}

Basic way to reduce noise when travelling by tram after the arc is the use of wheel flange lubrication. There are different technologies for lubricating wheel flanges and different types of lubricants (grease lubrication, spraying of mineral oil onto the wheel flange, etc.). It is important to choose the right lubricant so that the applied lubricant does not impair the vehicle's adhesion and increases its braking distance in emergency situations. Currently, every new low-floor tram is equipped with wheel flange lubrication (Fig. 5), which reduces noise and reduces rail wear on small radius arches.

LUBRICATION OF RAIL HEADS OR FLANGEWAYS

Another way to reduce noise can be lubrication of the rails. Wayside lubrication systems effectively apply a consistent and controlled volume of lubricant to the rail and hold that grease or friction modifier in place, allowing the wheels to grab and carry it around the track curve. Such a method can be used for gauge face and top-of-rail.

In wayside lubrication systems passing trains are detected by track-mounted wheel sensors. The applied lubricant is picked up by passing wheels, which carry the lubricant through the up-coming curves. Rail lubrication devices are independent of power sources. Usually, the energy obtained from the solar panel is used to apply the grease. But also the lubricator can be supplied from the municipal power network or the tram contact line. The central unit and the grease reservoir may be on pillars or walls of buildings. They can also be built underground or in a free-standing case.

Methods of wayside lubrication can be dived into two groups. The main factor of division here is the method of feeding grease or friction modifier:

1. On the wayside of the track with application bars,

2. On the wayside of the track thought drilled rails.

The first method of applying grease involves attaching a strip to the tram rail from which the lubricant is fed through point holes. This method is primarily used to lubricate the flange of tram wheels. It is used on railway rails (e.g. type 49E1), which are also used in tram infrastructure.

While a more common method used on grooved rails in tram tracks is to apply grease

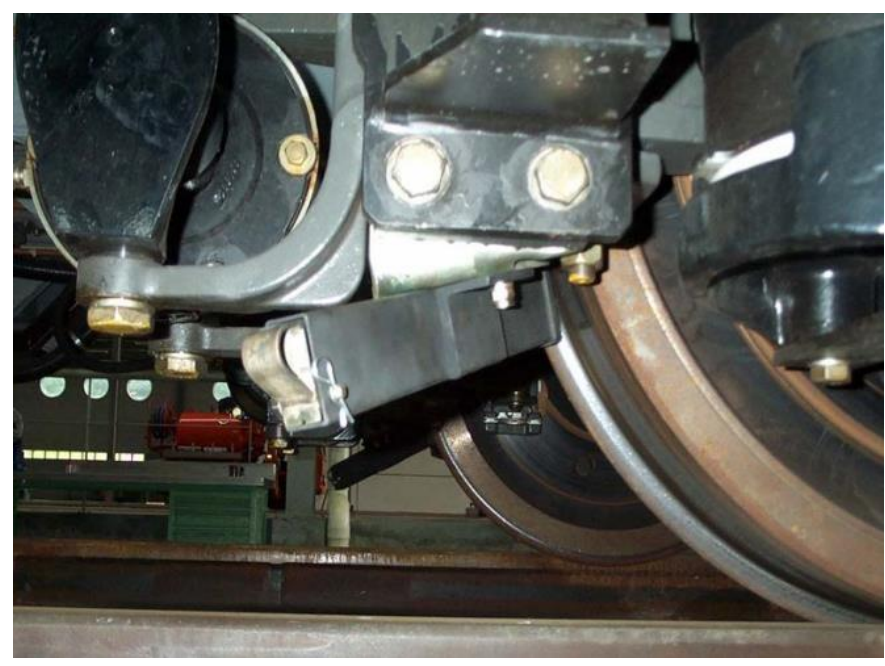

Fig. 5. Tram wheel flange lubrication device [13] 


\section{Ways of protection from noise pollution in railway and tramway infrastructure}

through holes drilled in the rail head (Fig. 6) or groove. In this method, grease is fed through the rail head onto the wheel running surface.

Each of these methods is aimed at: reducing the lateral wear of the rails, reducing the wear of the wheel flanges in the carriages, limiting the squeaks during the tram crossing [14].

\section{MODERN TRAMWAY TRACK STRUCTURE}

Modern track structure ensures good vibration insulation, and with adequate filling of the space between the rails also reduces noise. A good example of a quiet tramway surface is the track, where the rails are mounted on a concrete slab, and the space between it is filled with sand and then grass (Fig. 7) or sedum [15].

In case of tram surfaces also used as a roadway for other vehicles (like buses or cars), instead of filling with grass, the space between the rails is supplemented with concrete and asphalt. With the additional use of vibroinsulating material under the track plate and around the rails, the tramway surface significantly eliminates noise and vibration emissions during the passage of a tram or car vehicle [17].

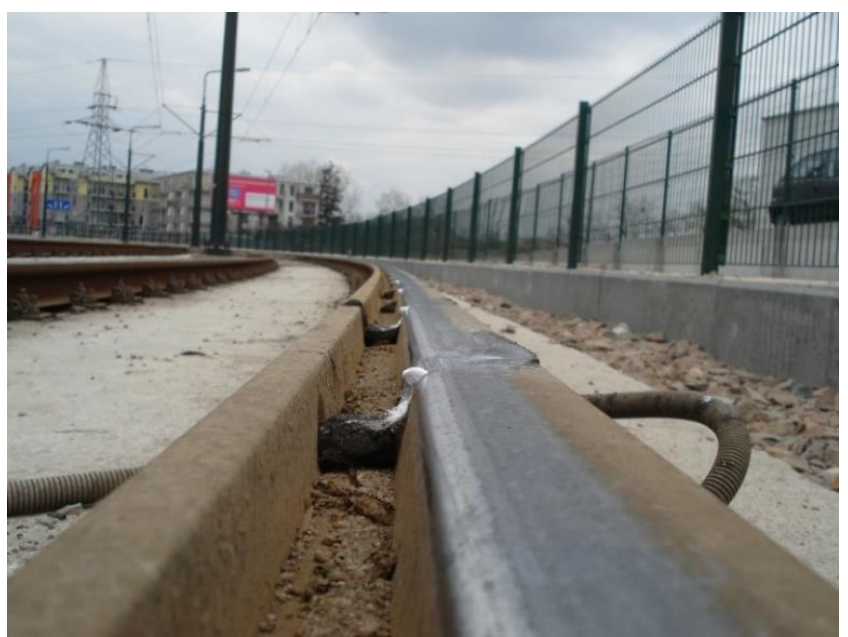

Fig. 6. Lube applicator through holes in the rail head on the tram curve in Krakow [14]

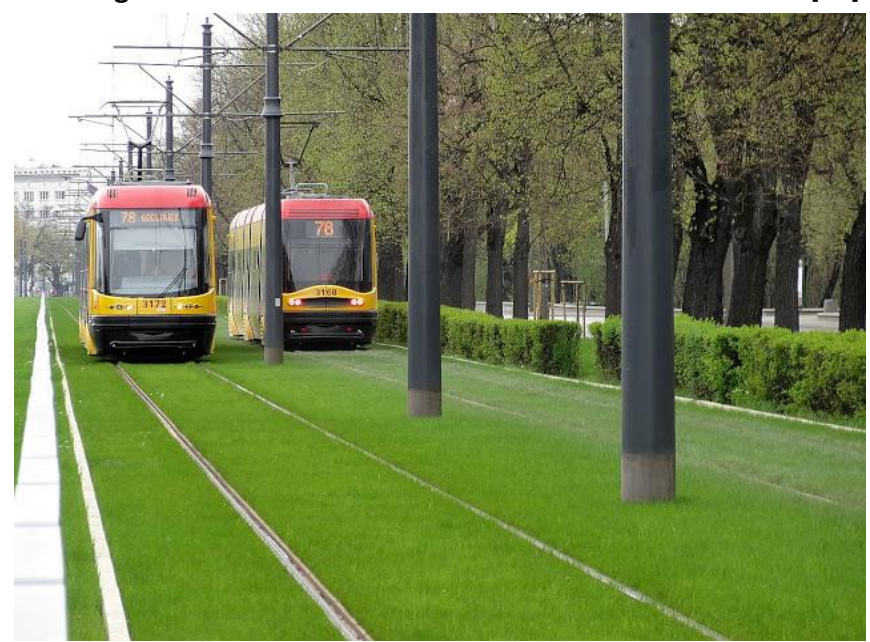

Fig. 7. Grass tram track in Warsaw [16] 
Table 1. Equivalent continuous sound level in day and night time at measuring points [13]

\begin{tabular}{|c|c|c|c|c|c|c|}
\hline \multirow{2}{*}{$\begin{array}{c}\text { Measuring } \\
\text { point }\end{array}$} & \multicolumn{5}{|c|}{$\begin{array}{c}\text { Equivalent continuous sound level during day time, } \\
\text { LAeqD [dB] }\end{array}$} & \multicolumn{3}{|c|}{ Equivalent continuous sound level during night time, } \\
LAeqN [dB]
\end{tabular}

\section{EVAluation OF THE EFFECTIVENESS OF NOISE} REDUCTION METHODS

The methods of noise protection or reduction in rail and tram infrastructure that were discussed in previous sections have been tested in many field studies. Most studies from the last few years have confirmed the effectiveness of the use of individual solutions in infrastructure $[13,19,20]$. However, there were cases when it was indicated that the use of noise protection measures did not improve the acoustic climate in the vicinity of the measuring point [18]. The attention should also be paid to the fact that these studies were conducted over 10 years ago. It can therefore be concluded that as technology progresses, its effectiveness also increases. The following sections present the results of studies that assessed the effectiveness of the use of noise protection measures in streetcar infrastructure.

\section{TRAM SURFACE TESTS}

\section{TRAMWAY TRACK ON OBOZOWA StREET, WARSAW}

In 2017, in Warsaw, on Obozowa Street, a tram track over 300 meters was renovated, on which an innovative tram surface with sedum was used. The advantage of such a solution is drought resistance, low temperatures and low involvement in maintaining greenery (mowing, watering). It is also a good method to reduce noise on straight sections of tram tracks [21].

Before (2017) and after (2018) renovation noise tests were carried out in two buildings located at Obozowa Street - Banderii 4 and Obozowa 20. Two measurement series were carried out during the day and at night. Based on the average results, the Table 1 has been prepared.

This research shows that the effect of track modernization using modern pavement was positive. The equivalent continuous sound level fell in both cases during the daytime and the night time, which improved the comfort of life for the local residents.

\section{TRAMWAY TRACKS IN POLISH CITIES}

In the years 1990-2010 vibroacoustic tests of the most popular tram track structures occurring in Poland were conducted [17]. The level of $L_{\max }$ sound emitted and the level of vibration during a tram passing the tested track section were checked. The purpose of the research was to show which track construction, commonly used in country, best limits noise and vibration emissions.

As research has shown, the greatest noise and vibration reduction was obtained on tracks built on concrete foundation with vibroinsulation elements where space between rails is filled with asphalt or paving. The level of sound emitted, compared to a typical ballast structure, is about $10 \mathrm{~dB}$ lower [17]. However, when it comes to tramway tracks common with road where construction of tram surface consists of concrete sleepers filled with asphalt located on the aggregate foundation without anti-vibration elements, the level of noise emission is higher by about $12 \mathrm{~dB}$ compared to modern solutions [17].

\section{EFFICIENCY TESTS OF TRACK LUBRICATORS}

When assessing the effectiveness of track lubricators, the tests were carried out on tram loops, where the radius of the curves is very small and amounts to about 20-25 meters.

\section{Tram Station nowe Bemowo, Warsaw}

The tram station is located in close proximity to multi-family buildings. At the loop in Bemowo, the noise level test was conducted on the u-turn curve with a radius of $R=25 \mathrm{~m}$. It is a track where all trams serving the tram station return so the track is frequently used. Tests were carried out for various types of trams before and after starting the track lubricator.

As it is shown in the presented test results in Table 2, the assembly of a track lubricator was justified and its efficiency depends on the type of tram passing on the track. 


\section{Ways of protection from noise pollution in railway and tramway infrastructure}

Table 2. Sound exposure level for different types of trams [13]

\begin{tabular}{|c|c|c|c|}
\hline \multirow{2}{*}{ Tram type } & \multicolumn{3}{|c|}{ Sound exposure level, LAE [dB] } \\
\cline { 2 - 4 } & Before lubrication & After lubrication & Difference \\
\hline Konstal 105 N & 95,3 & 86,4 & $-8,9$ \\
\hline Pesa Swing 120 N & 85,9 & 83,4 & $-2,5$ \\
\hline Pesa Jazz 128 N & 99,2 & 82,6 & $-16,6$ \\
\hline
\end{tabular}

\section{TRAM Station Starý LísKovec, Brno}

The noise level was measured in Brno at the tram station Starý Lískovec, which is located in the southern part of the city. The tram tracks are located next to the production areas, so in its neighbourhood they are not externally protected against noise, and an equivalent sound level has not been determined for the area. Tram station consists of two u-turn tracks, with a curvature radius $\mathrm{R}=30 \mathrm{~m}$. There are 3 types of trams on this section of the tram line: the modern low-floor articulated tram Skoda $13 \mathrm{~T}$, partly the low-floor articulated tram Tatra KT8 and the high-floor onesection tram Tatra T3.

As part of the study, two measuring points were created at a height of $1.5 \mathrm{~m}$ above the ground at a distance of $7.5 \mathrm{~m}$ from the first track to the tram station. During the tests, the sound exposure level (SEL) was checked at the crossing of individual

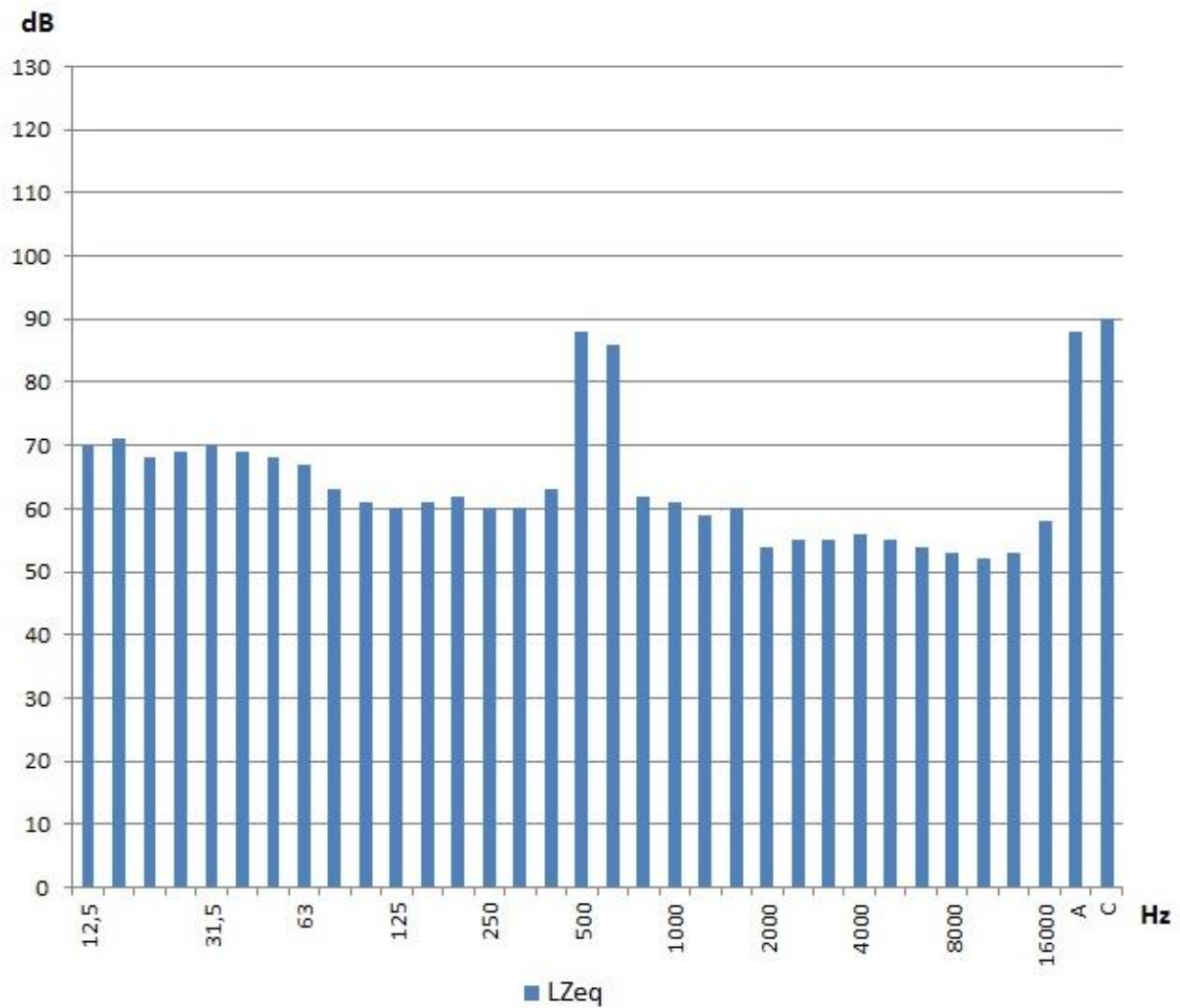

Fig. 8. Measurement for a KT8 tram before lubrication tram track [19] 
types of trams. The measurements were carried out in April 2017 for two days. Based on the tests performed, an equivalent sound level was calculated for the daytime and night time period.

The noise-reducing agent was a grease that was applied to the tram track through the holes in the rail head [19]. The results of tests for one of several KT8 tram crossings are presented on Figure 8 and 9.

Presented graphs shows that in the low frequency spectrum of sound, the differences between the track without lubrication and the track with lubrication are small. However, for higher frequencies, more troublesome for people, there was a decrease in equivalent sound level (Leq) by as much as about 10-20 dB.

To visualize the results better, an equivalent continuous sound level was calculated for the time of day and night. Research was conducted around the clock. 352 trams travelled through the tram station: 323 during the day and 29 at night. The speed of trams during the crossing was similar. The results of calculations are presented in the Table 3.

After applying lubrication in tracks at tram station, the noise load generated by tram traffic is $14.6 \mathrm{~dB}$ lower during the day and $14.4 \mathrm{~dB}$ at night than before use of lubricants.

Table 3. Equivalent continuous sound level in day and night time at measuring points [19]

\begin{tabular}{|c|c|c|c|c|c|}
\hline \multicolumn{3}{|c|}{$\begin{array}{l}\text { Equivalent continuous sound level during day time, } \\
\text { LAeqD [dB] }\end{array}$} & \multicolumn{3}{|c|}{ Equivalent continuous sound level during night time, } \\
LAeqN [dB]
\end{tabular}

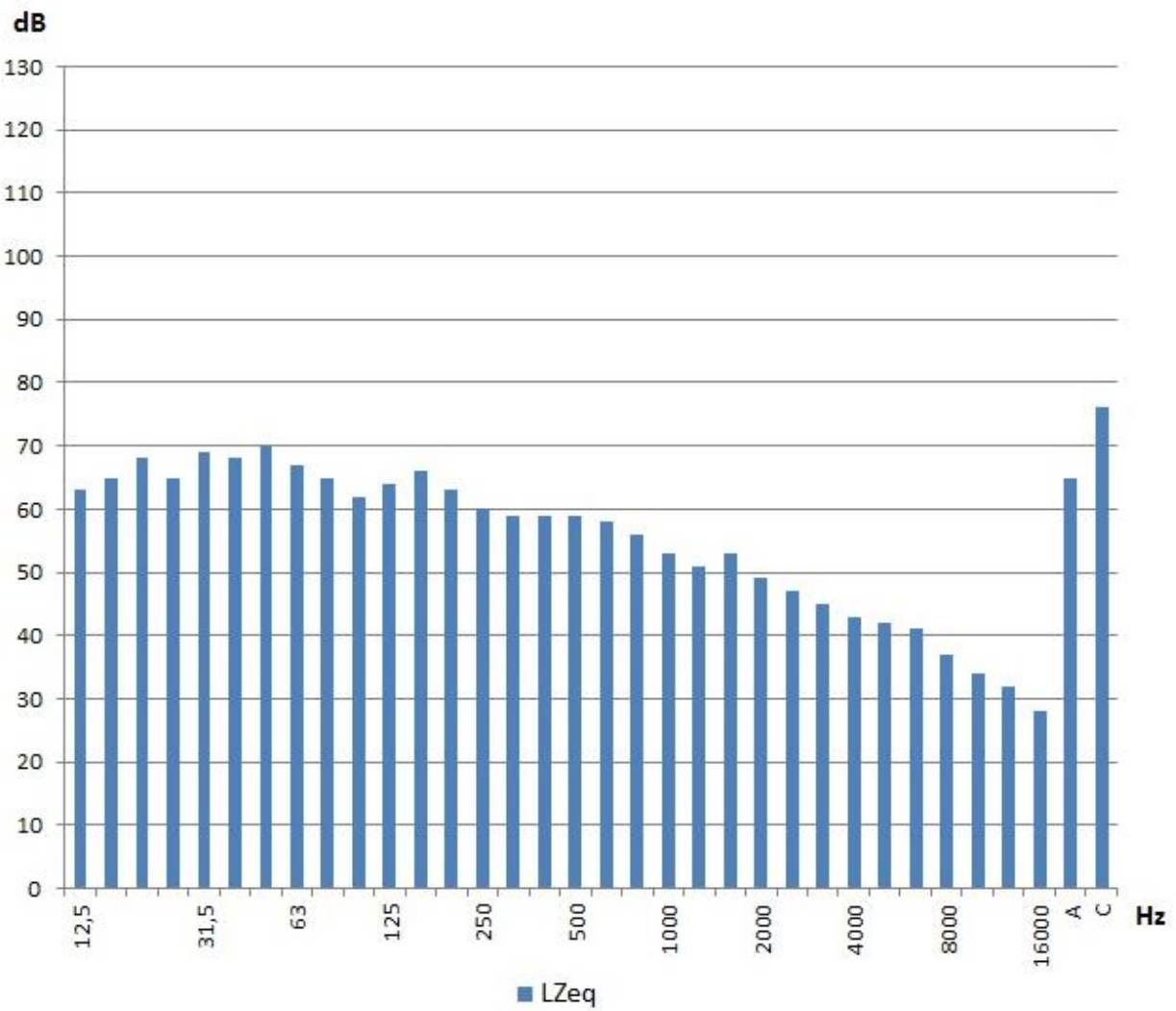

Fig. 9. Measurement for a KT8 tram after lubrication tram track [19] 


\section{Ways of protection from noise pollution in railway and tramway infrastructure}

Table 4. Sound exposure level for different types of trams [20]

\begin{tabular}{|c|c|c|c|}
\hline \multirow{2}{*}{ Tram type } & \multicolumn{3}{|c|}{ Sound exposure level, LAE [dB] } \\
\cline { 2 - 4 } & Before lubrication & After lubrication & Difference \\
\hline Duewag Pt8 & 97,6 & 79,7 & 17,9 \\
\hline Moderus Alfa & 104,3 & 78,7 & 25,6 \\
\hline Alstom-Konstal $116 \mathrm{Nd}$ & 93,2 & 80,1 & 13,1 \\
\hline Konstal $105 \mathrm{Na}$ & 100,7 & 80,0 & 20,7 \\
\hline
\end{tabular}

\section{Tram Station Stoneczna, Katowice}

As in the case of the tram track in Brno, the study in Katowice was conducted to answer the question whether the use of rail lubrication devices would improve the neighbourhood acoustic climate.

The track to be tested is a crossing track through the tram station, on which trams turn back at the loop or move further north (to Siemianowice Śląskie). The track is located on a curve with a radius $R=35 \mathrm{~m}$. There are 221 trams (181 during the day and 41 at night) of different types every day on this track. The tram station Słoneczna area is mainly office and service buildings and multi-family buildings. A two-lane road runs around the loop.

The measurements were carried out in March and May 2019. The reference source point was located 7.5 meters from the track edge at a height of 1.5 meters above the ground [20]. The rail lubrication device apply the lubricant through the holes in the rail heads. Table 4 shows the measurement results based on the study carried out.

For single-wagon vehicles such as Konstal $105 \mathrm{Na}$ and Moderus Alfa, it has been observed that the efficiency of the lubricator is greater than in the case of articulated wagons. This is due to a better distribution of weight among individual vehicle bogies in multi-unit wagons. However, for all types of trams it has been noticed that the use of a rail lubrication device significantly reduces the sound exposure level (SEL) by $13-26 \mathrm{~dB}$, which is a significant value affected on the acoustic comfort of the environment.

\section{CONCLUSIONS}

In the tram and railway infrastructure, noise sources are diversified. There are rolling noise, aerodynamic noise, traction noise and other sources of noise related to rolling stock dynamics and technical characteristics of vehicles.

However, noise can be reduced. Ways to reduce noise can be divided to reducing noise at the place of origin or at the place of spread. At the place of origin noise is reduced by rolling stock solutions, infrastructure solutions and friction reducing devises. At the place of spread sound can be reduced by earth ramparts, green belts or sound absorbing screens.

Other methods of noise protection are used in the tram infrastructure, such as: wheel flange lubrication, lubrication of rail heads or flangeways, ballastless tram track technology. Miscellaneous noise protection measures in the tram infrastructure result from different technical parameters of tramway infrastructure than the railway infrastructure.

The methods of reducing tram noise presented in the article have been repeatedly tested for their effectiveness. Most studies conducted in recent years have shown high efficiency of noise reduction measures. The use of modern tram surfaces with sedum on the track on Obozowa street in Warsaw gave the effect of lowering the equivalent continuous sound level by about $2 \mathrm{~dB}$. As far as rail tracks are used as a road the situation is similar. The tests that were carried out in different parts of the country indicated the effectiveness of noise reduction thanks to the use of modern rail surfaces [17].

On the other hand, track lubricators, used on tram stations on sharp curves, where the friction between the wheel and rail is the largest, showed significant efficiency in reducing noise. At the Nowe Bemowo tram station, tests have shown that thanks to the lubrication of the rails with a lubricant or friction reducer, the sound exposure level has been reduced by up to $16 \mathrm{~dB}$.

Research in Brno has shown that on the track with the lubricator running, the equivalent sound level decreased, especially in the high frequency range, by about 10-20 dB. In contrast, equivalent continuous sound level for the entire period during the day and night decreased by over $14 \mathrm{~dB}$.

At the Słoneczna tram station in Katowice, the tram lubricator launched in April 2019, depending 
on the type of rolling stock, reduced the sound exposure level by $13-25 \mathrm{~dB}$.

As the research cited in the article shows, the methods of reducing noise in rail infrastructure are effective and it is necessary to analyze in problematic places each time whether such noise protection devices should be designed and built. Particularly, on tram stations located next to residential buildings, consideration should be given to installing track lubricators, which significantly reduce the noise of passing trams. The less noise there is in the environment, the more people will be healthier and will live longer, and their comfort of living will improve.

SPOSOBY OCHRONY PRZED HAtASEM
KOMUNIKACYJNYM W INFRASTRUKTURZE SZYNOWEJ
$W$ artykule zaprezentowano sposoby ochrony przed
hałasem komunikacyjnym stosowane w infrastrukturze
szynowej na terenie Polski. Omówiono jakie są źródła hałasu
w transporcie kolejowym i tramwajowym. Przeanalizowano
rozwiązania powszechnie spotykane na sieci kolejowej takie
jak ekrany akustyczne i tłumiki szynowe. W ramach
infrastruktury tramwajowej przedstawiono metodę ochrony
przed hałasem w postaci smarownic torowych na łukach
o małych promieniach. Dodatkowo omówiono nowoczesne
nawierzchnie tramwajowe, któremogą redukować hałas. Na
koniec dokonano oceny skuteczności metod ochrony przed
hałasem w infrastrukturze tramwajowej na podstawie
testów i badań.

\section{Słowa kluczowe: kolej, tramwaj, infrastruktura,} zanieczyszczenie hałasem

\section{BIBLIOGRAPHY}

[1] Enviromental noise guidelines for European Region, World Health Organization, Copenhagen 2018

[2] Marczak P. (2012) "Zagrożenia hałasem wybrane zagadnienia", Biuro Analiz i Dokumentacji Kancelarii Sejmu, Warszawa

[3] Kotus J. Modelowanie wybranych źródeł hałasu

[4] Czyczuła W., Kożuch B. (2015) "Hałas w otoczeniu linil kolejowych - porównanie hałasu emitowanego przez EMU 250 (pendolino) $\mathrm{i}$ inne pociągi kursujące po centralnej magistrali kolejowej"
[5] King W.F. (1977) "On the role of aerodynamically generated sound in determining radiated noise levels of high speed trains", Journal of Sound and Vibration, 54 (3), pp. 361-378

[6] Bohatkiewicz J., Hałucha M., "Pomiary i analizy hałasu kolejowego", www.edroga.pl [Dostęp: 03.11.2019]

[7] Polak K. (2018) "Sposoby minimalizacji emisji hałasu kolejowego w aglomeracji miejskiej"

[8] Dyrekcja generalna ds. polityk wewnętrznych Unii, Departament Polityczny B: Polityka strukturalna i polityka spójności, Transport i Turystyka, "Ograniczenie hałasu kolejowego", Bruksela 2012

[9] Makosz E., Kowalczyk K., Dudzikowski Ł. (2014) "Sposoby ochrony środowiska przed hałasem przy inwestycjach liniowych, część 2 - nowoczesne metody ochrony przed hałasem od inwestycji liniowych. Inne niż ekrany akustyczne sposoby redukcji hałasu i drgań od inwestycji liniowych kolejowych", PKP Polskie Linie Kolejowe S.A., Warszawa

[10] Tomaszewski F., Wojciechowska E. (2011) "Transport kolejowy a ochrona środowiska", Technical Transactions, Zeszyt 4, Kraków

[11] Zbiciak A., Kraśkiewicz C., Lipko C., Oleksiewicz W. (2016) "Viscoelastic dynamic models of resilient elements used in railway tracks", IPICSE-2016, MATEC Web of Conferences 86, DOI:10.1051/matecconf/20168601015

[12] Dumitriu M., I. Cruceanu C. (2017) "On the Rolling Noise Reduction by Using the Rail Damper", Journal of Engineering Science and Technology Review 10(6)(2017) 87-95

[13] Lechowska L. (2018) "Ograniczenie hałasu tramwajowego. Wybrane zagadnienia", Tramwaje Warszawskie

[14] Lubcon - materiały producenta [Dostęp: 06.11.2019]

[15] Effect and Function of Green Tracks, Institute of Agricultural and Urban Ecological Projects affiliated to HumboldtUniversity Berlin (IASP)

[16] www.skyscrapercity.com [Dostęp: 04.11.2019]

[17] Targosz J., Adamczyk J. (2012) "Badania i ocena wibroaktywności konstrukcji torowisk tramwajowych stosowanych w Polsce", Logistyka 3/2012

[18] Zariczny J., Grulkowski S. (2009) "Efektywność działania smarownic a redukcja hałasu generowanego na łukach linii tramwajowych", Technika Transportu Szynowego 9/2009

[19] Kostečka J. (2017) "Noise measurement protocol" 5/2017, Brno

[20] Żuchowski R. (2019) "Pomiary hałasu w sąsiedztwie torowiska tramwajowego na pętli Słoneczna przy al. Korfantego w Katowicach, EkoSound, Sosnowiec

[21] www.transport-publiczny.pl/mobile/warszawa-torowiskona-obozowej-zazieleni-sie-rozchodnikiem-56340.html [Dostęp: 10.11.2019]

[22] Adamczyk J. (2013) "Problemy z ekranami akustycznymi", Przegląd Komunikacyjny 12/2013 